\title{
Modelling respiration rate of shredded Galega kale for development of modified atmosphere packaging
}

\author{
Susana C. Fonseca ${ }^{a}$, Fernanda A.R. Oliveira ${ }^{b, *}$, Jesus M. Frias ${ }^{b}$, Jeffrey K. Brecht ${ }^{c}$, \\ Khe V. Chau ${ }^{\mathrm{d}}$ \\ ${ }^{a}$ Escola Superior de Biotecnologia, Universidade Católica Portuguesa, Rua Dr. António Bernardino de Almeida, 4200-072 Porto, Portugal \\ ${ }^{\mathrm{b}}$ Department of Process Engineering, University College Cork, Cork, Ireland \\ ${ }^{\mathrm{c}}$ Horticultural Sciences Department, University of Florida, 1217 Fifield Hall, Gainesville, FL 32611-0690, USA \\ d Agricultural and Biological Engineering Department, University of Florida, 37 Frazier Rogers Hall, Gainesville, FL 32611-0570, USA
}

Keywords: Fresh-cut produce; Gas composition effect; Respiratory quotient (RQ); Respiratory response to wounding; Temperature effect

\begin{abstract}
The design of modified atmosphere packaging (MAP) for fresh-cut produce requires an adequate model for prediction of respiration rate as a function of both temperature and gas composition. In this work, the $\mathrm{O}_{2}$ consumption and $\mathrm{CO}_{2}$ production rates of shredded Galega kale were studied. The storage temperatures used were $1,5,10,15$ and $20^{\circ} \mathrm{C}$. The atmospheres tested were all combinations of 1,5 and $10 \% \mathrm{v} / \mathrm{v} \mathrm{O}_{2}$ plus 0,10 and $20 \% \mathrm{v} / \mathrm{v} \mathrm{CO}_{2}$ with the balance being $\mathrm{N}_{2}$, as well as ambient air. Temperature was the variable with the greatest influence on respiration rate and the effect of gas composition increased with temperature. The dependence of respiration rate on gas composition was well described by a Michaelis-Menten type equation with uncompetitive $\mathrm{CO}_{2}$ inhibition. The respiratory quotient (RQ) was found to be constant for the range of temperatures and gas compositions tested and was equal to $0.93 \pm 0.01$. The constants of the Michaelis-Menten equation increased exponentially with temperature. The change over time of respiration rate of leaves exposed to air at $20^{\circ} \mathrm{C}$ was also analysed. It was observed that respiration rate decreased with time and that the ratio between the respiration rate of shredded and intact leaves was approximately constant in the period tested and equal to 2.8. (C) 2002 Elsevier Science Ltd. All rights reserved.
\end{abstract}

\section{Introduction}

In Portugal shredded Galega kale is a traditional fresh-cut vegetable. It is thinly shredded and consumed in a soup. Galega kale (Brassica oleracea var. acephala DC) is a headless leafy cabbage with long petioles and large midribbed leaves. It represents an important contribution to the total production and consumption of vegetables in Portugal (Almeida \& Rosa, 1996). This vegetable is very well adapted and grows all year round due to the mild winters and cool summers in Portugal (Monteiro \& Dias, 1996). Galega kale was found to have higher levels of protein, calcium and magnesium than other Brassica crops (Rosa \& Almeida, 1996). The potential market of shredded Galega kale is still unexploited by the food industry. The preparation and

\footnotetext{
${ }^{*}$ Corresponding author. Tel.: +353-21-490-2383; fax: +353-21-4270249.

E-mail address: faroliveira@ucc.ie (F.A.R. Oliveira).
}

preservation of shredded Galega kale is a challenging example in the fresh-cut produce's technology.

Due to damaged cells, fresh-cut products have shorter shelf life than intact products (Bolin \& Huxsoll, 1991). Thus, techniques for extending fresh-cut product shelf life may have a major impact on the fresh-cut market. Refrigeration is essential for the preservation of these products and modified atmosphere packaging (MAP) is an important complementary technique. MAP is an atmosphere modification that relies on the interplay between the natural process of produce respiration and gas exchange through the package, leading to a build-up of $\mathrm{CO}_{2}$ and depletion of $\mathrm{O}_{2}$. MAP retards respiration, ageing and oxidative reactions, and may suppress microbial growth (Gorris \& Tauscher, 1999, Chap. 19).

The success of MAP greatly depends upon the choice of packing materials and on the package design. The higher respiration rates of fresh-cut products, as well as their higher tolerance to $\mathrm{CO}_{2}$ in general, require the use of packaging materials with a high $\mathrm{O}_{2}$ transmission 


\begin{tabular}{|c|c|c|c|}
\hline \multicolumn{4}{|c|}{ Nomenclature } \\
\hline$F$ & flow rate $\left(\mathrm{ml} \mathrm{h}^{-1}\right)$ & $\phi, \gamma$ & Michaelis-Menten \\
\hline$f$ & model constant (Eq. (7)) (dimensionless) & & (Eq. (8)) $(\% \mathrm{v} / \mathrm{v})$ \\
\hline$M$ & product weight $(\mathrm{kg})$ & $\phi_{1}, \gamma_{1}$ & Michaelis-Menten equation constants (Eq. \\
\hline$R$ & respiration rate $\left(\mathrm{ml} \mathrm{kg}^{-1} \mathrm{~h}^{-1}\right)$ & & $(10))(\% \mathrm{v} / \mathrm{v})$ \\
\hline RQ & respiratory quotient (dimensionless) & $\rho$ & product density $\left(\mathrm{kg} \mathrm{ml}^{-1}\right)$ \\
\hline SD & standard deviation & $\tau$ & Weibull model time constant (Eq. (5)) (h) \\
\hline$T$ & temperature $\left({ }^{\circ} \mathrm{C}\right)$ & $\tau_{\mathrm{r}}$ & residence time of the air in the flow through \\
\hline$t$ & time $(\mathrm{h})$ & & system (h) \\
\hline & volume $(\mathrm{ml})$ & \multirow{2}{*}{\multicolumn{2}{|c|}{ Superscripts }} \\
\hline$y$ & volumetric concentration $(\% \mathrm{v} / \mathrm{v})$ & & \\
\hline \multirow{2}{*}{\multicolumn{2}{|c|}{ Greek symbols }} & $\exp$ & experimental \\
\hline & & int & intact leaves \\
\hline$\beta$ & $\begin{array}{l}\text { Weibull model scale constant (Eq. (5)) (di- } \\
\text { mensionless) }\end{array}$ & $\begin{array}{l}\text { pred } \\
\text { shr }\end{array}$ & $\begin{array}{l}\text { predicted by the model } \\
\text { shredded leaves }\end{array}$ \\
\hline$|\Delta y|$ & $\begin{array}{l}\text { absolute volumetric concentration change } \\
\text { during } \Delta t(\% \mathrm{v} / \mathrm{v})\end{array}$ & & $\begin{array}{l}\text { at jar inlet } \\
\text { at jar outlet }\end{array}$ \\
\hline$\Delta t$ & time interval (h) & 0 & at time zero in the flow through system \\
\hline & $\begin{array}{l}\text { Michaelis-Menten equation constant (Eq. (8)) } \\
\left(\mathrm{ml} \mathrm{kg}^{-1} \mathrm{~h}^{-1}\right)\end{array}$ & & at steady state in the flow through system \\
\hline & Michaelis-Menten equation constant & \multicolumn{2}{|c|}{ Subscripts } \\
\hline & (Eq. (10)) $\left(\mathrm{ml} \mathrm{kg}^{-1} \mathrm{~h}^{-1}\right)$ & $\mathrm{O}_{2}$ & oxygen \\
\hline$\alpha_{2}, \phi$ & $\begin{array}{l}2 \text { Michaelis-Menten equation constants } \\
(\text { Eq. }(10))\left({ }^{\circ} \mathrm{C}^{-1}\right)\end{array}$ & $\begin{array}{l}\mathrm{CO}_{2} \\
\mathrm{f}\end{array}$ & $\begin{array}{l}\text { carbon dioxide } \\
\text { free }\end{array}$ \\
\hline
\end{tabular}

rate and alternative materials and packaging systems are being investigated, such as laser microperforated films and microporous membranes (Mannapperuma \& Singh, 1994; Zagory, 1997) or perforation-mediated MAP (Fonseca, Oliveira, Lino, Brecht, \& Chau, 2000). The design of a MA package requires a mathematical model relating respiration rate (both $\mathrm{O}_{2}$ consumption and $\mathrm{CO}_{2}$ production rates) to storage temperature and gas composition. Respiration involves a very complex set of biochemical reactions, which impairs the development of mechanistic models. The Michaelis-Menten equation has been thoroughly reported in the literature as giving good fits to experimental data on respiration rate of different products (Andrich, Fiorentini, Tuci, Zinnai, \& Sommovigo, 1991; Cameron, Beaudry, Banks, \& Yelanich, 1994; Hertog, Peppelenbos, Evelo, \& Tijkens, 1998; Joles, Cameron, Shirazi, Petracek, \& Beaudry, 1994; Lee, Haggar, Lee, \& Yam, 1991; Lee, Song, \& Yam, 1996; McLaughlin \& Berine, 1999; Peppelenbos \& van't Leven, 1996; Peppelenbos, van't Leven, van Zwol, \& Tijskens, 1993; Ratti, Raghavan, \& Gariépy, 1996; Solomos \& Kanellis, 1989). $\mathrm{CO}_{2}$ is often assumed to have an inhibitory effect on respiration, either uncompetitive, non-competitive or uncompetitive/competitive (Lee et al., 1991, 1996; McLaughlin \& Berine, 1999; Peppelenbos \& van't Leven, 1996; Renault, Souty, \& Chambroy, 1994). The parameters of the model are however not true Michaelis-Menten constants describ- ing a simple quasi-equilibrium enzymatic reaction, and therefore the choice of the inhibition mechanism is simply based on the quality of the fit and/or on the simplicity of the model.

The objectives of this work were: (i) to analyse the change over time of respiration rate of Galega kale after shredding, (ii) to analyse the influence of $\mathrm{O}_{2}$ and $\mathrm{CO}_{2}$ concentrations and temperature on the respiration rate, and (iii) to develop a predictive model relating respiration rate to $\mathrm{O}_{2}$ and $\mathrm{CO}_{2}$ concentrations and temperature that may be used in the design of MAP for this product.

\section{Materials and methods}

\subsection{Produce and sample preparation}

Galega kale plants were grown in the horticultural fields of the University of Florida, Gainesville, USA. Leaves at full maturity were picked early in the morning and transported immediately to the experimental site. The leaves were selected on the basis of uniform colour and absence of defects. The midrib was excised with a sharp knife and discarded. The leaves with midribs removed were washed to remove dirt and insects, shredded in a hand shredder machine ( $1.5 \mathrm{~mm}$ wide), washed with chlorinated water $(100 \mathrm{ppm})$ for $30 \mathrm{~s}$, and centrifuged in 
a salad spinner to remove excess water. Intact leaves, not subjected to any treatment, were used as control.

\subsection{Change of respiration rate after shredding}

Shredded or intact leaves were placed in 1.71 glass jars and weighed (approximately $150 \mathrm{~g}$ ). The jar lids had stoppers for gas sampling and rubber tubes for gas flow. The inlet tube was inserted down to the bottom of the jar to ensure uniform flushing of the gas mixture. The jars were stored in a cold room at $20 \pm 0.5{ }^{\circ} \mathrm{C}$ and a flow through system was used to allow to quantify the $\mathrm{CO}_{2}$ production rate over time. A humidified stream of air at $20^{\circ} \mathrm{C}$ was fed to the jars at a flow rate of $1.51 \mathrm{~h}^{-1}$. The gas stream was humidified by bubbling in deionised water to avoid water loss that might influence the respiration rate. Weight variations were monitored and found to be less than $0.74 \%$ of the initial weight. Gas samples of $0.5 \mathrm{ml}$ were taken at the jar inlet and outlet at selected sampling times with a $1.0 \mathrm{ml} \mathrm{BD}$ (Benton Dickinson, Rutherford, NJ, USA) plastic syringe with $23 \mathrm{G} 1 \mathrm{BD}$ needles. $\mathrm{CO}_{2}$ production rate $\left(R_{\mathrm{CO}_{2}}\right)$ at a given time was calculated from a mass balance:

$F \times y_{\mathrm{CO}_{2}}^{\text {out }}=F \times y_{\mathrm{CO}_{2}}^{\text {in }}+100 \times R_{\mathrm{CO}_{2}} \times M-V_{\mathrm{f}} \times \frac{\mathrm{d} y_{\mathrm{CO}_{2}}^{\text {out }}}{\mathrm{d} t}$,

where $F$ is the gas flow rate, $y_{\mathrm{CO}_{2}}^{\text {in }}$ and $y_{\mathrm{CO}_{2}}^{\text {out }}$ are the $\mathrm{CO}_{2}$ concentrations in the gas stream at the jar inlet and outlet, respectively, $M$ is the weight of product in the jar and $V_{\mathrm{f}}$ is the free volume inside the jar. $V_{\mathrm{f}}$ can be calculated as

$V_{\mathrm{f}}=V-M / \rho$,

where $V$ is the volume of the jar and $\rho$ is the true density of the kale $\left(1.0 \times 10^{-3} \mathrm{~kg} \mathrm{ml}^{-1}\right)$.

Two replicates were performed both for shredded and intact leaves. In order to assess jar seal effectiveness, a gas mixture of known composition was flushed into a jar with no produce, the jar sealed, and the gas composition measured over time; no variations of concentration were noticed.

\subsection{Influence of gas composition and temperature on respiration rate}

The respiration rate was analysed at $1,5,10,15$, and $20{ }^{\circ} \mathrm{C}$. The atmosphere tested were: (i) all combinations of approximately 1,5 , and $10 \% \mathrm{v} / \mathrm{v} \mathrm{O}_{2}$ and 0,10 , and $20 \% \mathrm{v} / \mathrm{v} \mathrm{CO}$ with the balance $\mathrm{N}_{2}$ and (ii) ambient air. The exact composition of the atmospheres used is shown in Table 1. These gas concentrations are within normal values recommended for MAP of fresh-cut products and the range of temperatures covers normal distribution and retail conditions. Three replicates were performed for each set of conditions.

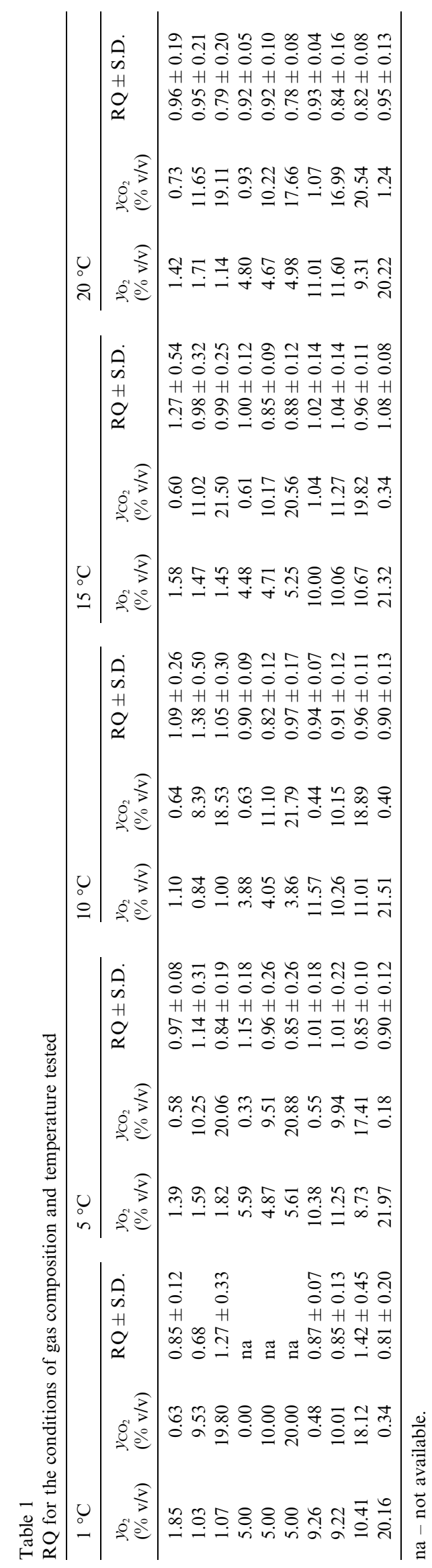


The closed system was chosen to measure the respiration rate. Shredded kale was placed in 1.71 glass jars and weighed (approximately $150 \mathrm{~g}$ ). The jar lids had stoppers for gas sampling and rubber tubes for gas flow as described before. The jars were stored at different temperatures in cold rooms equipped with a gas mixing board and flushed with the humidified selected mixtures of $\mathrm{O}_{2}, \mathrm{CO}_{2}$, and $\mathrm{N}_{2}$ for $24 \mathrm{~h}$ before measurements, to equilibrate the samples (the flow rate inside each jar was constant and equal to $61 \mathrm{~h}^{-1}$ ). The gas flow was then halted, the gas stream inlet and outlet closed, and gas samples of $0.5 \mathrm{ml}$ were withdrawn from the jars. Other samples were withdrawn at given times up to $560 \mathrm{~min}$, depending on temperature conditions. Changes in gas composition during these periods were smaller than $4 \%$ $\mathrm{v} / \mathrm{v}$. At least two samples were taken from each jar at different times.

$\mathrm{O}_{2}$ consumption and $\mathrm{CO}_{2}$ production rates were determined as:

$R=\frac{V_{\mathrm{f}} \times|\Delta y|}{100 \times M \times \Delta t}$,

where $|\Delta y|$ is the absolute value of concentration changes during the time interval $\Delta t$.

\subsection{Gas concentration analysis}

The gas samples were analysed with a Gow-Mac series 580 gas chromatograph (Gow-Mac Instrument, Bridgewater, NJ, USA) and a HP 3396 series II integrator (Hewlett Packard, Avondale, PA, USA). The gas chromatograph was equipped with two columns in series and a thermal conductivity detector. One column was a porous polymer column (80-100 mesh Columpak PQ) and the other was a molecular sieve $5 \mathrm{~A}$ column (60-80 mesh). The gas carrier was helium at a pressure of 275 $\mathrm{kPa}$ and a flow rate of $1.81 \mathrm{~h}^{-1}$. Temperature of both columns was set at $44{ }^{\circ} \mathrm{C}$ and temperature of injector and detector was set at $90{ }^{\circ} \mathrm{C}$. Calibration of the gas chromatograph was performed using a single calibration mixture of $7.04 \% \mathrm{v} / \mathrm{v} \mathrm{O}_{2}$ and $7.03 \% \mathrm{v} / \mathrm{v} \mathrm{CO}_{2}$.

\subsection{Model parameter estimation}

The model constants were estimated by fitting the model to the experimental data by non-linear regression using the Statistica software (release 5.1, 97 edition, Statsoft, Tulsa, OK, USA).

\section{Results and discussion}

\subsection{Modelling the change of $\mathrm{CO}_{2}$ production rate after shredding}

A preliminary analysis of the change of $\mathrm{CO}_{2}$ production rate with time was done by calculating its value at every experimental time, using Eq. (1) after a simple manipulation

$R_{\mathrm{CO}_{2}}=\frac{F}{100 \times M} \times\left(y_{\mathrm{CO}_{2}}^{\text {out }}-y_{\mathrm{CO}_{2}}^{\text {in }}\right)+\frac{V_{\mathrm{f}}}{100 \times M} \times \frac{\mathrm{d} y_{\mathrm{CO}_{2}}^{\text {out }}}{\mathrm{d} t}$.

This analysis showed that: (i) the ratio between the $\mathrm{CO}_{2}$ production rate of shredded and intact kale was constant with time and equal to 2.8 , (ii) $\mathrm{CO}_{2}$ production rate decreased with time, and (iii) this dependence could be well described by the Weibull model levelling off to an equilibrium value (Seber \& Wild, 1989, Chap. 7; Weibull, 1951):

$\frac{R_{\mathrm{CO}_{2}}-R_{\mathrm{CO}_{2}}^{\infty}}{R_{\mathrm{CO}_{2}}^{0}-R_{\mathrm{CO}_{2}}^{\infty}}=\mathrm{e}^{-(t / \tau)^{\beta}}$,

where $R_{\mathrm{CO}_{2}}, R_{\mathrm{CO}_{2}}^{0}$ and $R_{\mathrm{CO}_{2}}^{\infty}$ are the $\mathrm{CO}_{2}$ production rates at time $t$, at the beginning of the experiment and when the system becomes stable, respectively, and $\tau$ and $\beta$ are the model constants, respectively, a time and a scale parameter.

Substituting Eq. (5) in Eq. (1) and integrating the resulting equation with respect to time, we get

$$
\begin{aligned}
y_{\mathrm{CO}_{2}}^{\text {out }}=y_{\mathrm{CO}_{2}}^{\text {in }}+\frac{100 \times M}{V_{\mathrm{f}}} \times\left[\tau_{\mathrm{r}} \times R_{\mathrm{CO}_{2}}^{\infty} \times\left(1-\mathrm{e}^{-t / \tau_{\mathrm{r}}}\right)\right. \\
\left.+\frac{R_{\mathrm{CO}_{2}}^{0}-R_{\mathrm{CO}_{2}}^{\infty}}{1 / \tau_{\mathrm{r}}-\left(\beta \times t^{\beta-1}\right) / \tau^{\beta}} \times\left(\mathrm{e}^{-(t / \tau)^{\beta}}-\mathrm{e}^{-t / \tau_{\mathrm{r}}}\right)\right],
\end{aligned}
$$

where $\tau_{\mathrm{r}}$ is the residence time of the air in the jar $\left(=V_{\mathrm{f}} / F\right)$.

Because the ratio between the $\mathrm{CO}_{2}$ production rate of shredded and intact kale is constant with time, Eq. (6) may be re-written as

$$
\begin{aligned}
y_{\mathrm{CO}_{2}}^{\text {out }}=y_{\mathrm{CO}_{2}}^{\text {in }} & +\frac{100 \times M}{f \times V_{\mathrm{f}}}\left[\tau_{\mathrm{r}} \times R_{\mathrm{CO}_{2}}^{\infty, \text { shr }}\left(1-\mathrm{e}^{-t / \tau_{\mathrm{r}}}\right)\right. \\
& \left.+\frac{R_{\mathrm{CO}_{2}}^{0, \text { shr }}-R_{\mathrm{CO}_{2}}^{\infty, \text { shr }}}{1 / \tau_{\mathrm{r}}-\left(\beta \times t^{\beta-1}\right) / \tau^{\beta}}\left(\mathrm{e}^{-(t / \tau)^{\beta}}-\mathrm{e}^{-t / \tau_{\mathrm{r}}}\right)\right],
\end{aligned}
$$

where $R_{\mathrm{CO}_{2}}^{0, \text { shr }}$ and $R_{\mathrm{CO}}^{\infty}$,shr are the $\mathrm{CO}_{2}$ production rates of shredded kale at the beginning of the experiment and at steady-state, respectively, and $f$ is 1 for shredded kale and 2.8 for intact kale.

Fig. 1 shows the change of $\mathrm{CO}_{2}$ production rate with time both for shredded and intact Galega kale leaves at $20^{\circ} \mathrm{C}$ under ambient air. This dependence was estimated by fitting Eq. (7) to the $\mathrm{CO}_{2}$ concentration measured in the gas stream at the jar outlet with the flow through system. Fig. 2 shows the good relationship between the experimental data and the model and Table 2 summarises the estimates of the constants and relevant statistical data. The model fits the data well, as shown by the statistical data: all the parameters are significant, the 


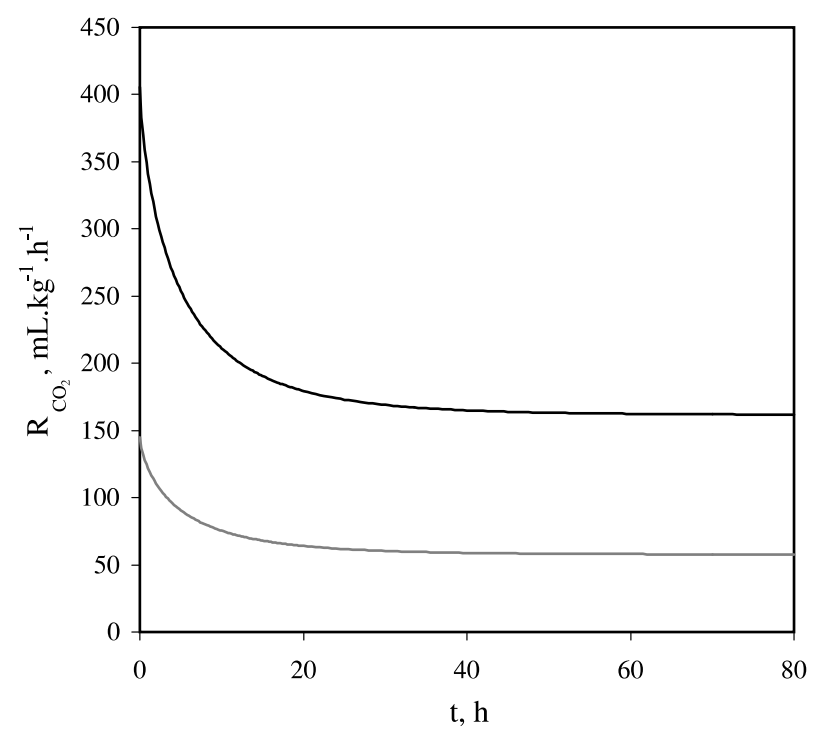

Fig. 1. Change of $\mathrm{CO}_{2}$ production rate with time at ambient air and $T=20{ }^{\circ} \mathrm{C}$, using Eq. (5) and the model constants in Table 2 (shredded leaves, - intact leaves).

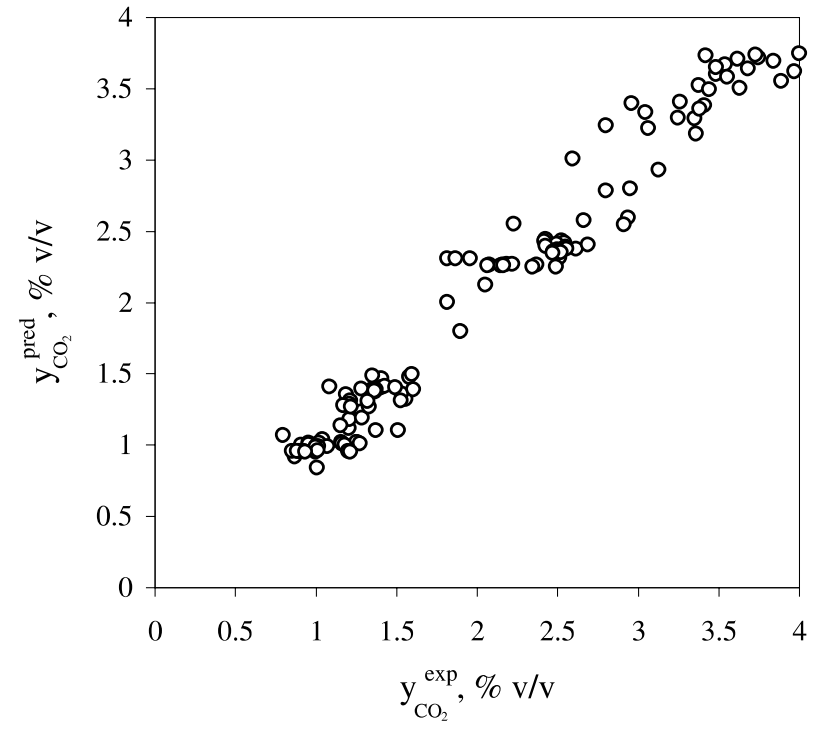

Fig. 2. Relationship between $\mathrm{CO}_{2}$ concentration measured in the gas stream at the jar outlet in the experiments for determination of $\mathrm{CO}_{2}$ production rate with the flow through system, and the values predicted using Eq. (7) and the model constants in Table 2. correlation between parameters is small, and the variance explained by the model is high.

As shown in Fig. 1, $\mathrm{CO}_{2}$ production rates decreased with time and levelled off at 161.7 and $57.8 \mathrm{ml} \mathrm{kg}^{-1} \mathrm{~h}^{-1}$, respectively, for shredded and intact leaves, after $24 \mathrm{~h}$. Smyth, Song, \& Cameron (1998) have also reported a decrease of $\mathrm{CO}_{2}$ production rate over time for cut Iceberg lettuce at $5{ }^{\circ} \mathrm{C}$ under $\mathrm{CO}_{2}$-scrubbed air. In terms of packaging design, this pattern of respiration rate change with time would only affect the time needed to achieve steady state concentrations. Thus, it would be advantageous to pack the product as soon as possible, as the initial respiration rate $\left(405.5\right.$ and $144.8 \mathrm{ml} \mathrm{kg}^{-1} \mathrm{~h}^{-1}$, respectively, for shredded and intact leaves) is approximately threefold that at steady state.

The greater respiration rates of shredded leaves (approximately threefold that of intact leaves) most probably are due both to the physiological response to wounding (Brecht, 1995) and to increased surface area (Bastrash, Makhlouf, Castaigne, \& Willemot, 1993). Respiration rate increases from 2 to 3 times that of intact fruit were reported for apple slices (Lakakul, Beaudry, \& Hernandez, 1999).

\subsection{Influence of gas composition and temperature on respiration rate}

The $\mathrm{O}_{2}$ consumption $\left(R_{\mathrm{O}_{2}}\right)$ and $\mathrm{CO}_{2}\left(R_{\mathrm{CO}_{2}}\right)$ production rates of Galega kale ranged from $5.6 \pm 1.6$ to $161 \pm 22 \mathrm{ml} \mathrm{kg}^{-1} \mathrm{~h}^{-1}$ and from $7.9 \pm 1.1$ to $153 \pm$ $4 \mathrm{ml} \mathrm{kg}{ }^{-1} \mathrm{~h}^{-1}$, respectively, over all the combinations of $\mathrm{O}_{2}$ levels, $\mathrm{CO}_{2}$ levels, and storage temperatures tested (Fig. 3). Respiration rate decreased with a decrease in $\mathrm{O}_{2}$ concentration and temperature, and increased with a decrease in $\mathrm{CO}_{2}$ concentration. Temperature was the variable with the greatest effect on respiration rate: lowering the temperature of samples stored in air from 20 to $1{ }^{\circ} \mathrm{C}$ decreased $R_{\mathrm{CO}_{2}}$ and $R_{\mathrm{O}_{2}}$ by $90 \%$ and $88 \%$, respectively, whereas changing the atmosphere composition from air to $1 \% \mathrm{v} / \mathrm{v} \mathrm{O}_{2}$ and $20 \% \mathrm{v} / \mathrm{v} \mathrm{CO}_{2}$ at $20{ }^{\circ} \mathrm{C}$ decreased $R_{\mathrm{CO}_{2}}$ and $R_{\mathrm{O}_{2}}$ by 80 and $76 \%$, respectively. At $1{ }^{\circ} \mathrm{C}$, changing the atmospheric composition from air to $1 \% \mathrm{v} / \mathrm{v} \mathrm{O}_{2}$ and $20 \% \mathrm{v} / \mathrm{v} \mathrm{CO}_{2}$ decreased $R_{\mathrm{CO}_{2}}$ and $R_{\mathrm{O}_{2}}$ by

Table 2

Parameter estimates of the mathematical model describing the change of respiration rate with time (Eq. (5)) and relevant statistical data

\begin{tabular}{|c|c|c|c|c|}
\hline \multirow[t]{2}{*}{ Model constant } & \multirow{2}{*}{ Estimate \pm S.E. } & \multicolumn{3}{|c|}{ Correlation coefficient between the model constants } \\
\hline & & $R_{\mathrm{CO}_{2}}^{0, \mathrm{shr}}$ & $R_{\mathrm{CO}_{2}}^{\infty, \text { shr }}$ & $\tau$ \\
\hline$R_{\mathrm{CO}_{2}}^{0, \mathrm{shr}}\left(\mathrm{ml} \mathrm{kg}^{-1} \mathrm{~h}^{-1}\right)$ & $405.5 \pm 23.5$ & & & \\
\hline$R_{\mathrm{CO}_{2}}^{\infty}\left(\mathrm{ml} \mathrm{kg}^{-1} \mathrm{~h}^{-1}\right)$ & $161.7 \pm 4.9$ & 0.074 & & \\
\hline$\tau(\mathrm{h})$ & $5.2 \pm 1.1$ & -0.815 & -0.555 & \\
\hline$\beta$ (dimensionless) & $0.72 \pm 0.06$ & -0.727 & 0.450 & 0.262 \\
\hline$N=129$ & & $R^{2}=96.3 \%$ & & \\
\hline
\end{tabular}

$N$ - number of experimental points, $R^{2}$ - variance explained by the model. 

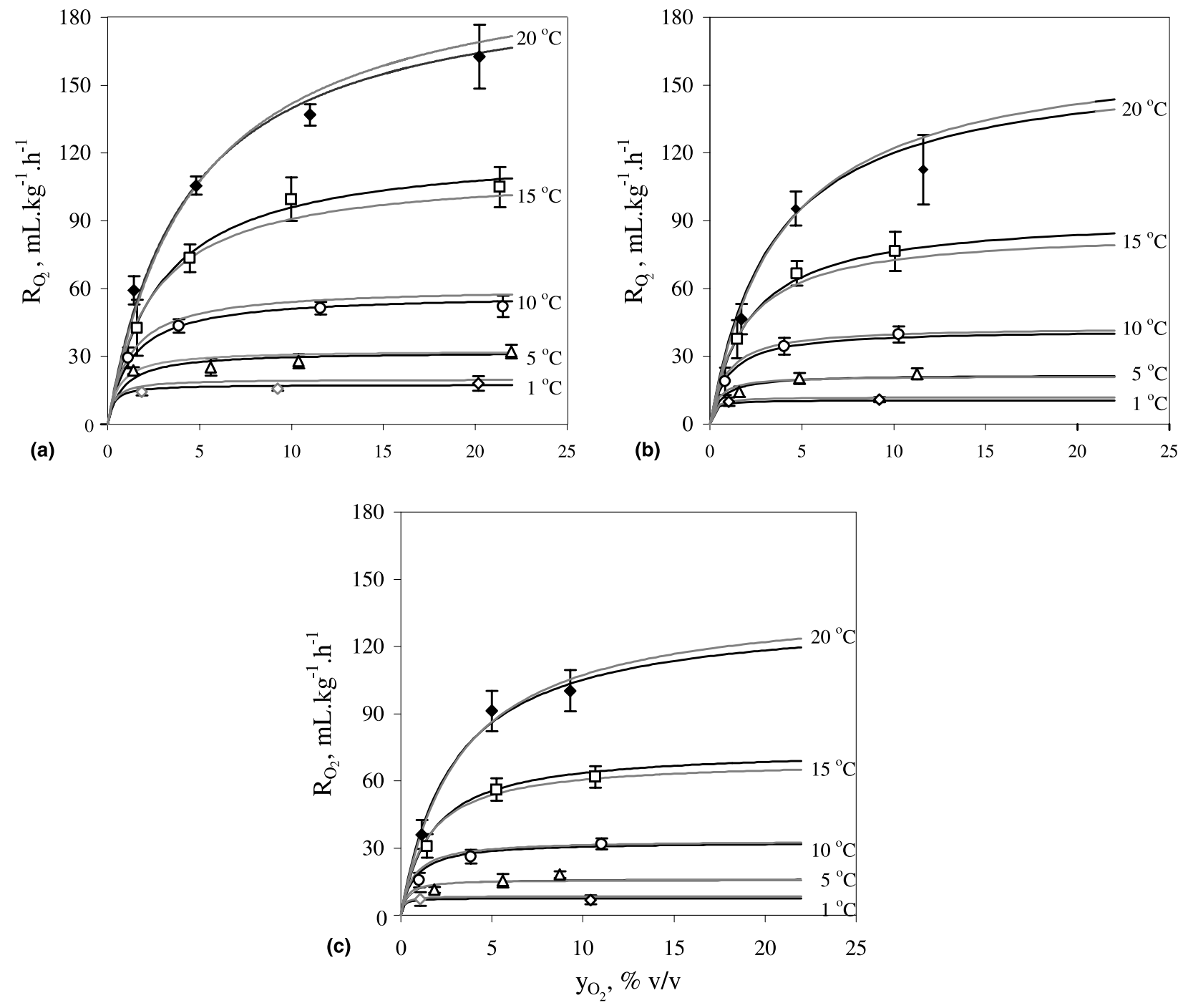

Fig. 3. $\mathrm{O}_{2}$ consumption rates for the different gas concentrations and temperatures tested: (a) $y_{\mathrm{CO}_{2}}=0 \%$; (b) $y_{\mathrm{CO}_{2}}=10 \%$; (c) $y_{\mathrm{CO}_{2}}=20 \%\left(\diamond T=1{ }^{\circ} \mathrm{C}\right.$, $\Delta T=5{ }^{\circ} \mathrm{C}, \bigcirc T=10{ }^{\circ} \mathrm{C}, \square T=15^{\circ} \mathrm{C}, \diamond T=20^{\circ} \mathrm{C}$, — individual model, — overall model). The bars represent the standard deviation.

only $50 \%$ and $68 \%$, respectively. These results stress the importance of cooling in the extension of fresh-cut produce shelf life and show that the effect of gas composition is more important at above optimum temperatures, as previously reported by Kader (1987) and Emond, Chau, and Brecht (1993).

The respiratory quotient (RQ), ratio of $\mathrm{CO}_{2}$ production and $\mathrm{O}_{2}$ consumption rates, ranged from $0.81 \pm 0.20$ to $1.4 \pm 0.5$ and did not show any dependence on temperature or gas composition (Table 1). These values are within the range of those reported in the literature regarding aerobic respiration (Kader, Zagory, \& Kerbel, 1989). Thus, there was no evidence of anaerobic respiration for the conditions of temperature and gas composition tested and one can assume that the RQ breakpoint of shredded kale (lowest $\mathrm{O}_{2}$ concentration that does not induce anaerobic respiration) is lower than $1 \% \mathrm{v} / \mathrm{v} \mathrm{O}_{2}$ in the range of temperatures tested. The
RQ value estimated by linear regression of $R_{\mathrm{CO}_{2}}$ vs. $R_{\mathrm{O}_{2}}$ was equal to $0.93 \pm 0.01\left(R^{2} \mathrm{adj}=99.2 \%\right)$.

\subsection{Modelling the influence of gas composition and temperature on respiration rate}

The dependence of respiration on gas composition was modelled by a Michaelis-Menten type equation, with $\mathrm{O}_{2}$ as substrate and $\mathrm{CO}_{2}$ uncompetitive inhibition and constant RQ

$$
\begin{aligned}
& R_{\mathrm{O}_{2}}=\frac{\alpha \times y_{\mathrm{O}_{2}}}{\phi+y_{\mathrm{O}_{2}} \times\left(1+\left(y_{\mathrm{CO}_{2}}\right) / \gamma\right)}, \\
& \mathrm{RQ}=\frac{R_{\mathrm{CO}_{2}}}{R_{\mathrm{O}_{2}}},
\end{aligned}
$$

where $R_{\mathrm{O}_{2}}$ and $R_{\mathrm{CO}_{2}}$ are the $\mathrm{O}_{2}$ consumption and the $\mathrm{CO}_{2}$ production rate, respectively, $y_{\mathrm{O}_{2}}$ and $y_{\mathrm{CO}_{2}}$ are the 

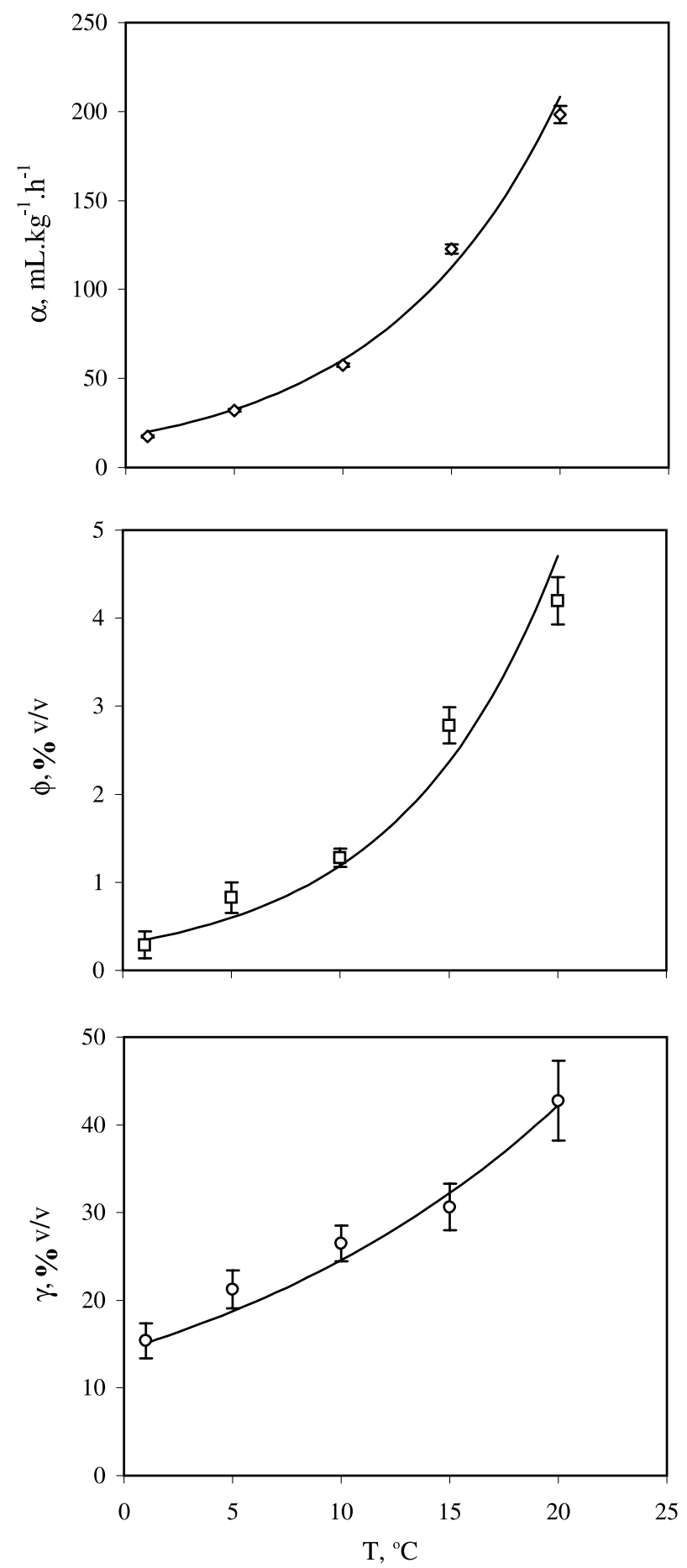

Fig. 4. Dependence of the constants of the Michaelis-Menten equation (Eq. (8)) on temperature. The dots represent the estimates of the individual model (the bars represent the standard error of the estimates), whereas the lines represent the fit of the overall model.

volumetric percentages of $\mathrm{O}_{2}$ and $\mathrm{CO}_{2}$, respectively, and $\alpha, \phi$ and $\gamma$ are the model constants. Fig. 3 shows the fit of this model to the experimental data $\left(78.2 \% \leqslant R^{2} \leqslant\right.$ $94.2 \%)$. Similar fits were obtained when assuming noncompetitive and uncompetitive/competitive inhibition mechanisms, yet the non-competitive model was found to be structurally indistinguishable from the selected model (Walter \& Pronzato, 1997) and the uncompetitive/competitive model has a greater number of constants. The constants of the model $(\alpha, \phi$ and $\gamma)$ increased exponentially with temperature (Fig. 4). This dependence was included in Eq. (8), yieldinga global model that describes the effects of both gas composition and temperature $(T)$ on respiration rate

$R_{\mathrm{O}_{2}}=\frac{\alpha_{1} \times \mathrm{e}^{\left(\alpha_{2} \times T\right)} \times y_{\mathrm{O}_{2}}}{\phi_{1} \times \mathrm{e}^{\left(\phi_{2} \times T\right)}+y_{\mathrm{O}_{2}} \times\left(1+\left(y_{\mathrm{CO}_{2}}\right) /\left(\gamma_{1} \times \mathrm{e}^{\left(\gamma_{2} \times T\right)}\right)\right)}$.

Eqs. (9) and (10) where then fitted to the whole set of experimental data by non-linear regression, estimating the model constants $\alpha_{1}, \alpha_{2}, \phi_{1}, \phi_{2}, \gamma_{1}$ and $\gamma_{2}$. The model appropriately describes both the influence of gas composition and temperature, as shown by the high $R^{2}$ $(96.6 \%)$. The scatter plot in Fig. 5 shows the fair agreement between predicted and experimental respiration rates, both for $\mathrm{O}_{2}$ consumption and $\mathrm{CO}_{2}$ production rates. Table 3 summarises the estimates of the model constants and relevant statistical data. The correlation between the model constants was generally low, except between the constants $\alpha_{1}$ and $\alpha_{2}, \phi_{1}$ and $\phi_{2}$ and $\gamma_{1}$ and $\gamma_{2}$ (correlation coefficients of $0.96,0.98$ and 0.96 , respectively). However, absolute values below 0.99 are considered acceptable (Bates \& Watts, 1988).

The $\mathrm{CO}_{2}$ production rate of shredded leaves under air at $20{ }^{\circ} \mathrm{C}$ predicted by the model is $158 \mathrm{ml} \mathrm{kg}^{-1} \mathrm{~h}^{-1}$, which is within the standard error of $R_{\mathrm{CO}_{2}}^{\infty, \text { shr }}$ reported in Table 2.

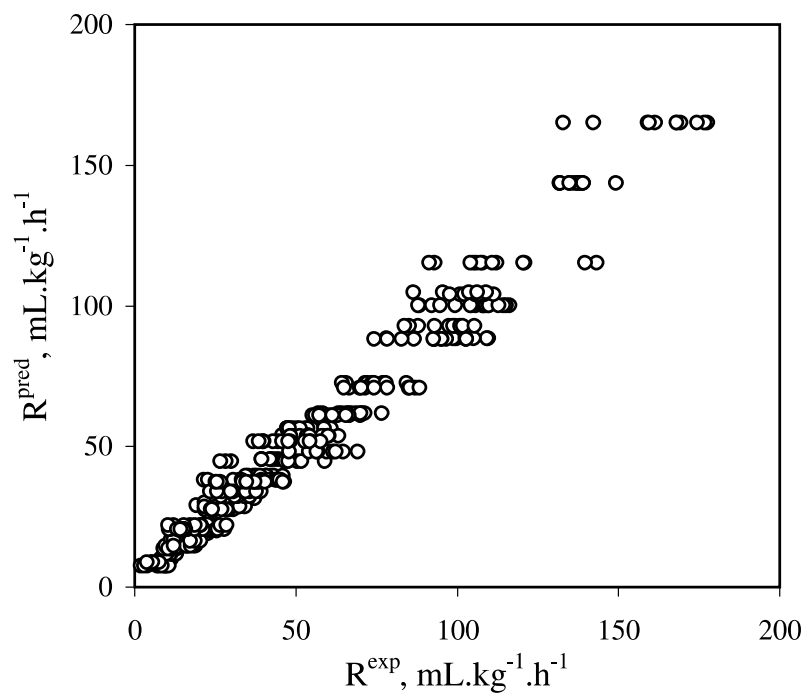

Fig. 5. Relationship between experimental respiration rates and those predicted using the Michaelis-Menten equation with $\mathrm{CO}_{2}$ uncompetitive inhibition, assuming an exponential dependence of the model constants on temperature (Eq. (10)) and constant RQ. 
Table 3

Parameter estimates of the mathematical model describing the influence of gas composition and temperature on respiration rate (Eqs. (9) and (10)) and relevant statistical data

\begin{tabular}{lllrrl}
\hline Model constant & Estimate \pm S.E. & \multicolumn{4}{l}{ Correlation coefficient between the model constants } \\
\cline { 3 - 6 } & & $\alpha_{1}$ & $\alpha_{2}$ & $\phi_{1}$ & $\phi_{2}$ \\
\hline$\alpha_{1}\left(\mathrm{ml} \mathrm{kg}^{-1} \mathrm{~h}^{-1}\right)$ & $17.6 \pm 0.7$ & & & & \\
$\alpha_{2}\left({ }^{\circ} \mathrm{C}^{-1}\right)$ & $0.124 \pm 0.002$ & -0.96 & -0.62 & & \\
$\phi_{1}(\% \mathrm{v} / \mathrm{v})$ & $0.30 \pm 0.06$ & 0.67 & 0.69 & -0.98 & 0.03 \\
$\phi_{2}\left({ }^{\circ} \mathrm{C}^{-1}\right)$ & $0.14 \pm 0.01$ & -0.69 & 0.46 & -0.02 & -0.04 \\
$\gamma_{1}(\% \mathrm{v} / \mathrm{v})$ & $14.3 \pm 2.3$ & -0.48 & -0.47 & 0.03 & -0.96 \\
$\gamma_{2}\left({ }^{\circ} \mathrm{C}^{-1}\right)$ & $0.05 \pm 0.01$ & 0.45 & & & \\
$N=480$ & & $R^{2}=96.6 \%$ & & & \\
\hline
\end{tabular}

\section{Conclusions}

Both intact and shredded Galega kale leaves stored in air at $20{ }^{\circ} \mathrm{C}$ showed a decrease of $\mathrm{CO}_{2}$ production rate with time, the initial value being approximately threefold that at steady state. Under these conditions, the respiration rate of shredded leaves was 2.8 times that of intact leaves. Temperature was the variable with the greatest influence on respiration rate and the effect of gas composition was found to increase with temperature. This stresses the importance of product refrigeration and suggests that the use of MAP is more important when the product is handled at above optimum temperature. The RQ was independent of both temperature and gas composition within the ranges of those variables that were tested. A Michaelis-Menten type equation with $\mathrm{O}_{2}$ as substrate, uncompetitive inhibition of $\mathrm{CO}_{2}$ and an exponential increase of the equation constants with temperature appropriately described the effect of temperature and gas composition on respiration rate. This model may be used to design an appropriate MA package for shredded kale, although further studies are required to analyse the effect of time on respiration rate at different temperatures and gas composition.

\section{Acknowledgements}

The first author acknowledges financial support from Fundação para a Ciência e Tecnologia, Portugal through programme PRAXIS XXI.

\section{References}

Almeida, D., \& Rosa, E. (1996). Protein and mineral concentration of Portuguese kale (Brassica oleracea var. acephala) related to soil composition. Acta Horticulturae, 407, 269-276.

Andrich, G., Fiorentini, R., Tuci, A., Zinnai, A., \& Sommovigo, G. (1991). A tentative model to describe respiration of stored apples. Journal of the American Society for Horticultural Science, 116(3), $478-481$.
Bastrash, S., Makhlouf, J., Castaigne, F., \& Willemot, C. (1993). Optimal controlled atmosphere conditions for storage of broccoli florets. Journal of Food Science, 58(2), 338-341, 360.

Bates, D. M., \& Watts, D. G. (1988). Nonlinear regression analysis and its applications. USA: Wiley.

Bolin, H. R., \& Huxsoll, C. C. (1991). Effect of preparation procedures and storage parameters on quality retention of salad-cut lettuce. Journal of Food Science, 56(1), 60-67.

Brecht, J. K. (1995). Physiology of lightly processed fruits and vegetables. HortScience, 30(1), 18-21.

Cameron, A. C., Beaudry, R. M., Banks, N. H., \& Yelanich, M. V. (1994). Modified atmosphere packaging of blueberry fruit: modeling respiration and package oxygen partial pressures as a function of temperature. Journal of the American Society for Horticultural Science, 119(3), 534-539.

Emond, J. P., Chau, K. V., \& Brecht, J. K. (1993). Modeling respiration rates of blueberry in a perforation-generated modified atmosphere package. In G. D. Blanpied, J. A. Barstch, \& J. R. Hicks (Eds.), Proceedings of the 6th international controlled atmosphere research conference, Ithaca, NY, USA (Vol. 1) (pp. 134-144).

Fonseca, S. C., Oliveira, F. A. R., Lino, I. B. M., Brecht, J. K., \& Chau, K. V. (2000). Modelling $\mathrm{O}_{2}$ and $\mathrm{CO}_{2}$ exchange for development of perforation-mediated modified atmosphere packaging. Journal of Food Engineering, 43(1), 9-15.

Gorris, L., \& Tauscher, B. (1999). Quality and safety aspects of novel minimal processing technology. In F. A. R. Oliveira, \& J. C. Oliveira (Eds.), Processing of foods: Quality optimisation and process assessment (pp. 325-339). USA: CRC Press.

Hertog, M. L. A. T. M., Peppelenbos, H. W., Evelo, R. G., \& Tijkens, L. M. M. (1998). A dynamic and generic model of gas exchange of respiring produce: the effects of oxygen, carbon dioxide and temperature. Postharvest Biology and Technology, 14, 335349.

Joles, D. W., Cameron, A. C., Shirazi, A., Petracek, P. D., \& Beaudry, R. M. (1994). Modified atmosphere packaging of 'Heritage' red raspberry fruit: respiratory response to reduced oxygen, enhanced carbon dioxide and temperature. Journal of the American Society for Horticultural Science, 119(3), 540-545.

Kader, A. A. (1987). Respiration and gas exchange of vegetables. In J. Weichmann (Ed.), Postharvest physiology of vegetables (pp. 25-43). NY, USA: Marcel Dekker.

Kader, A. A., Zagory, D., \& Kerbel, E. L. (1989). Modified atmosphere packaging of fruits and vegetables. Critical Reviews in Food Science and Nutrition, 28(1), 1-30.

Lakakul, R., Beaudry, R. M., \& Hernandez, R. J. (1999). Modeling respiration of apple slices in modified-atmosphere packages. Journal of Food Science, 64(1), 105-110.

Lee, D. S., Haggar, P. E., Lee, J., \& Yam, K. L. (1991). Model for fresh produce respiration in modified atmospheres based on 
principles of enzyme kinetics. Journal of Food Science, 56(6), 15801585.

Lee, D. S., Song, Y., \& Yam, K. L. (1996). Application of an enzyme kinetics based respiration model to permeable system experiment of fresh produce. Journal of Food Engineering, 27(3), 297-310.

Mannapperuma, J. D., \& Singh, R. P. (1994). Modeling of gas exchange in polymeric packages of fresh fruits and vegetables. In R. P. Singh, \& F. A. R. Oliveira (Eds.), Process optimisation and minimal processing of foods (pp. 437-445). NY, USA: Elsevier.

McLaughlin, C. P., \& Beirne, D. (1999). Respiration rate of a dry coleslaw mix as affected by storage temperature and respiratory gas concentrations. Journal of Food Science, 64, 116-119.

Monteiro, A. A., \& Dias, J. S. (1996). Portuguese Brassica landraces: a perspective. Acta Horticulturae, 407, 87-93.

Peppelenbos, H. W., \& van't Leven, J. (1996). Evaluation of four types of inhibition for modelling the influence of carbon dioxide on oxygen consumption fruits and vegetables. Postharvest Biology and Technology, 7(1/2), 27-40.

Peppelenbos, H. W., van't Leven, J., van Zwol, B. H., \& Tijskens, L. M. M. (1993). The influence of $\mathrm{O}_{2}$ and $\mathrm{CO}_{2}$ on the quality of fresh mushrooms. In G. D. Blanpied, J. A. Barstch, \& J. R. Hicks (Eds.), Proceedings of the 6th international controlled atmosphere research conference, Ithaca, NY, USA (Vol. 2) (pp. 746-758).
Ratti, C., Raghavan, G. S. V., \& Gariépy, Y. (1996). Respiration rate model and modified atmosphere packaging of fresh cauliflower. Journal of Food Engineering, 28(3-4), 297-306.

Renault, P., Souty, M., \& Chambroy, Y. (1994). Gas exchange in modified atmosphere packaging 1: a new theoretical approach for micro-perforated packs. International Journal of Food Science and Technology, 29(4), 365-378.

Rosa, E., \& Almeida, D. (1996). The influence of growing season on protein and mineral content of several Brassica crops. Acta Horticulturae, 407, 261-268.

Seber, G. A. F., \& Wild, C. J. (1989). Growth models. In Nonlinear regression (p. 325). NY, USA: Wiley.

Smyth, A. B., Song, J., \& Cameron, A. C. (1998). Modified atmosphere packaged cut Iceberg lettuce: effect of temperature and $\mathrm{O}_{2}$ partial pressure on respiration and quality. Journal of Agricultural and Food Chemistry, 46, 4556-4562.

Solomos, T., \& Kanellis, A. (1989). Low oxygen and fruit ripening. Acta Horticulturae, 258, 151-160.

Walter, E., \& Pronzato, L. (1997). Identification of parametric models from experimental data. Great Britain: Masson.

Weibull, W. (1951). A statistical distribution function of wide applicability. Journal of Applied Mechanics, 18, 293.

Zagory, D. (1997). Advances in modified atmosphere packaging (MAP) of fresh produce. Perishables Handling Newsletter, 90, 2-4. 